\title{
APLIKASI KOMPOS TANDAN KOSONG KELAPA SAWIT PADA TANAMAN KARET MENGHASILKAN
}

\author{
Application Of Oil Palm Empty Bunches Compost In Mature Rubber \\ Jamin Saputra dan Charlos Togi Stevanus \\ Balai Penelitian Sembawa, Pusat Penelitian Karet \\ Jalan Palembang - Pangkalan Balai KM 29, Palembang 30001, Indonesia \\ Email : jamincomsu@yahoo.com
}

Diterima 24 September 2018 / Direvisi 16 Mei 2019 / Disetujui 28 Mei 2019

\begin{abstract}
Abstrak
Tandan kosong kelapa sawit merupakan limbah terbesar dibandingkan limbah padat lainnya di perkebunan kelapa sawit. Sekitar $23 \%$ dari tandan buah segar menjadi tandan kosong kelapa sawit. Hal tersebut merupakan potensi yang besar untuk bahan baku pembuatan kompos.Tujuan penelitian ini adalah untuk mengetahui pengaruh penggunaan kompos dari tandan kosong kelapa sawit dan kombinasinya dengan pupuk kimia terhadap pertumbuhan dan produksi pada tanaman karet menghasilkan. Penelitian dilakukan di Kebun Percobaan Balai Penelitian Sembawa dari tahun 2014 sampai 2016. Penelitian dilaksanakan dengan menggunakan tanaman karet klon PB 260 dengan tahun tanam 2001. Penelitian menggunakan Rancangan Acak Kelompok (RAK) yang terdiri atas 6 perlakuan, 4 ulangan dan setiap ulangan terdiri atas 49 tanaman. Perlakuan yang diuji terdiri atas: (1) Kontrol (tanpa pemupukan), (2) 100\% dosis umum pupuk kimia, (3) $2 \mathrm{~kg}$ kompos, (4) $1,6 \mathrm{~kg}$ kompos $+25 \%$ dosis umum pupuk kimia, (5) $1,2 \mathrm{~kg}$ kompos $+50 \%$ dosis umum pupuk kimia, (6) $0,8 \mathrm{~kg}$ kompos $+75 \%$ dosis umum pupuk kimia. Pengamatan dilakukan terhadap kandungan hara tanah dan tanaman, pertumbuhan lilit batang, tebal kulit pulihan, dan produksi tanaman selama dua tahun. Hasil penelitian menunjukkan bahwa perlakuan kompos $1,2 \mathrm{~kg}+50 \%$ dosis umum
\end{abstract}

berpengaruh nyata terhadap pertumbuhan lilit batang dan produksi tanaman karet. Penggunaan kompos dengan dosis 1,2 - 1,6 kg mampu menurunkan penggunaan pupuk kimia sebesar $50-75 \%$.

Kata kunci: kompos, tandan kosong kelapa sawit, lilit batang, tebal kulit pulihan, produksi lateks

\section{Abstract}

Oil palm empty bunches are the largest waste of oil palm plantations. Approximately 23\% of the fresh fruit bunches into oil palm empty bunches. This is a large potential for composting raw materials. The purpose of this study was to determine the use of compost from empty bunches of palm oil and its combination with inorganic fertilizers on the growth and production of the rubber tree. This research was conducted at Sembawa Research Centre Experimental Field from 2014 to 2016. The observed field was $P B 260$ which planted rubber clone planted in 2001. The study used Randomized Block Design consisting of 6 surfaces, 4 replicates, and each replication consist of 49 plants. The treatments were consisting of: (1) Control (without fertilizer), (2) $100 \%$ of inorganic fertilizer general dose, (3) $2 \mathrm{~kg}$ of compost, (4) $1,6 \mathrm{~kg}$ of compost $+25 \%$ of inorganic fertilizer general dosage, (5) $1.2 \mathrm{~kg}$ of compost $+50 \%$ of anorganic fertilizer general dose, (6) $0.8 \mathrm{~kg}$ of compost $+75 \%$ of inorganic fertilizer general dose. Parameter observed were the soil and leaf nutrient, girth, the renewed bark thickness, and latex yield. 
The results showed that treatment of $1,2 \mathrm{~kg}$ compost $+50 \%$ general dosage had a significant effect on stem growth and latex yield. The used of $1,2 \mathrm{~kg}$ until $1,6 \mathrm{~kg}$ compost can decreased inorganic fertilizer by $50-75 \%$.

Keywords: compost, oil palm empty bunches, girth, renewed bark thickness, latex yield

\section{Pendahuluan}

Pengolahan kelapa sawit menjadi minyak sawit menghasilkan beberapa jenis limbah padat yang meliputi tandan kosong sawit, cangkang dan serat mesokarp. Tandan kosong merupakan limbah terbesar dibandingkan limbah padat lainnya di perkebunan kelapa sawit. Tandan kosong kelapa sawit (TKKS) merupakan limbah yang dihasilkan sebanyak $\pm 23 \%$ dari tandan buah segar (TBS). Menurut Direktorat Jenderal Perkebunan (2018) produksi Crude Palm Oil (CPO) tahun 2018 mencapai 41,6 juta ton, dengan rendemen COP 25\% dari TBS maka produksi TBS mencapai 172 juta ton dan potensi TKKS mencapai 39,5 juta ton. Cangkang dan serat mesokarp merupakan bagian buah kelapa sawit. Limbah berupa cangkang dan serat diperoleh setelah proses pengepresan buah. Limbah berupa cangkang sebesar $5 \%$ dari TBS. Limbah ini biasanya dipakai sebagai bahan bakar ketel. Limbah serat pada Pabrik Kelapa Sawit (PKS) sebanyak 15\% dari Tandan Buah Segar (TBS). Bentuknya halus dan memiliki kadar air yang cukup rendah. Serat memiliki kadar zat kering $62 \%$ (Mangoensoekardjo \& Semangun, 2005). TKKS merupakan bahan yang mengandung unsur N, P, K dan Mg. TKKS sangat potensial dimanfaatkan sebagai kompos karena jumlahnya yang melimpah dan kadar haranya yang tinggi (Darnoko \& Sembiring, 2005; Wijaya et al., 2010). Setiap ton TKKS mengandung unsur hara yang setara dengan 3 kg Urea; 0,6 kg Rock Posphat; 12 kg KCL, dan 2 kg Kieserit (Loong et al., 1987).

Perkebunan karet di Indonesia umumnya diusahakan pada jenis tanah Ultisol. Tanah Ultisol dicirikan oleh tingkat kemasaman tinggi, kandungan hara makro dan mikro yang rendah (Hidayat \& Mulyani, 2002) serta kandungan bahan organik yang rendah karena proses dekomposisi berjalan cepat dan sebagian terbawa erosi (Prasetyo \& Suriadikarta, 2006). Kondisi ini akan menghambat pertumbuhan dan perkembangan tanaman karet. Berbagai upaya dapat dilakukan untuk meningkatkan kesuburan tanah Ultisol, di antaranya adalah dengan penambahan unsur hara melalui pupuk anorganik (Prasetyo \& Suriadikarta, 2006), organik, maupun pupuk hayati. Kompos sebagai salah satu jenis pupuk organik selain menyuplai hara bagi tanaman juga berperan untuk menambah bahan organik tanah dan memperbaiki sifat fisik, kimia, dan biologitanah.

Umumnya penggunaan kompos lebih banyak diterapkan pada tanaman semusim atau hortikultura, sedangkan untuk tanaman perkebunan seperti tanaman karet masih sangat terbatas. Pada saat ini telah banyak diproduksi kompos yang berasal dari limbah pabrik pengolahan kelapa sawit berupa tandan kosong merupakan sumber bahan baku potensial untuk dibuat kompos. Telah banyak penelitian pengaruh kompos dari TKKS terhadap perbaikan tanah dan pertumbuhan serta produksi tanaman pertanian. Saputra \& Stevanus (2017) melakukan penelitian pengaruh pupuk kompos dari tandan kosong kelapa sawit dan dikombinasikan dengan pupuk kimia terhadap pertumbuhan tanaman karet belum menghasilkan, hasilnya menunjukkan bahwa perlakuan $100 \%$ dosis umum pupuk kimia memiliki pertambahan lilit batang tanaman karet belum menghasilkan yang paling tinggi $(10,40 \mathrm{~cm})$, namun tidak berbeda nyata dengan perlakuan kompos $1,5 \mathrm{~kg}+25 \%$ dosis umum pupuk kimia $(10,20 \mathrm{~cm})$ dan kompos $1 \mathrm{~kg}+50 \%$ dosis umum pupuk kimia $(10,30 \mathrm{~cm})$.

Pada tanaman lain Junaedi (2012) melaporkan bahwa penggunaan pupuk kompos dapat meningkatkan pertumbuhan tinggi dan diameter rata-rata bibit meranti tembaga asal cabutan alam sebesar $47 \%$ dan $42 \%$ dibandingkan tanpa kompos dan pupuk. 
bibit Meranti tembaga. Hasil penelitian Zulkarnain et al. (2013) menunjukkan bahwa penambahan pupuk kandang dan kompos dapat meningkatkan dan berpengaruh nyata terhadap kadar C-organik dan nitrogen tanah. Hasil penelitian Sukandar et al. (2014) menyatakan bahwa penggunaan campuran kompos TKKS dan abu boiler yang dikombinasikan dengan pupuk nitrogen berpengaruh terhadap peningkatan produksi tanaman padi. Hasil penelitian Asra et al. (2015) menunjukkan bahwa aplikasi kompos TKKS memiliki pengaruh yang nyata terhadap total luas daun $(42,8 \%$ dari kontrol) bibit kelapa sawit di pre nursery. Harbianto et al. (2015) melaporkan bahwa pemberian kombinasi pupuk kompos TKKS dan abu boiler kelapa meningkatkan tinggi tanaman, jumlah umbi, diameter umbi, berat umbi layak simpan dan berat segar umbi bawang merah.

Tujuan penelitian ini adalah untuk mengetahui pengaruh penggunaan kompos dari tandan kosong kelapa sawit dan kombinasinya dengan pupuk kimia terhadap pertumbuhan dan produksi pada tanaman karet menghasilkan.

\section{Bahan dan Metode}

Penelitian dilakukan tahun 2014-2016 di Kebun Percobaan Balai Penelitian Sembawa pada tanaman karet menghasilkan. Klon karet yang digunakan adalah PB 260 tahun tanam 2001. Jarak tanam tanaman karet $6 \times 3 \mathrm{~m}$, sehingga populasinya 555 pohon/ha. Pupuk kimia yang digunakan adalah pupuk tunggal Urea, TSP, $\mathrm{KCl}$, dan Kieserit dengan kandungan hara masing-masing 46\% N, 36\% $\mathrm{P}_{2} \mathrm{O}_{5}, 60 \% \mathrm{~K}_{2} \mathrm{O}$ dan $26 \% \mathrm{MgO}$. Pupuk organik yang digunakan adalah pupuk kompos dari tandan kosong kelapa sawit dengan komposisi hara C-Organik (42-54\%), N (3-5\%), C/N Rasio (15-20), $\mathrm{P}_{2} \mathrm{O}_{5}(0,4-1 \%), \mathrm{K}_{2} \mathrm{O}(2,9-5,2 \%)$, $\mathrm{MgO}(0,7-0,94 \%), \mathrm{CaO}(2,27-3,69 \%)$ dan $\mathrm{pH}$ 7-8.

Kandungan hara tanah sebelum dilakukan penelitian pada lokasi penelitian disajikan pada Tabel 1. Berdasarkan klasifikasi hara untuk tanaman karet (Adiwiganda et al., 1994), tanah tersebut memiliki $\mathrm{pH}$ tanah yang sangat masam, kandungan $\mathrm{C}$ organik tanah yang sangat tinggi, hara $\mathrm{N}$ termasuk sedang, hara $\mathrm{P}_{2} \mathrm{O}_{5}$ termasuk sedang, sedangkan hara $\mathrm{K}, \mathrm{Ca}$, dan $\mathrm{Mg}$ tergolong sangat rendah, dengan KTK yang tergolong rendah. Hal ini menunjukkan bahwa tanah pada lokasi penelitian memiliki kandungan hara yang sangat rendah sehingga apabila tidak dilakukan pemupukan maka tanaman karet tidak akan tumbuh dan berproduksi secara optimal.

Tabel 1. Kandungan hara tanah pada lokasi penelitian

\begin{tabular}{lcc}
\hline Parameter & Nilai & Status* \\
\hline $\mathrm{pH}$ & 4,82 & Sangat Masam \\
\hline $\mathrm{N}(\%)$ & 0,23 & Sedang \\
\hline $\mathrm{C}$ organik $(\%)$ & 4,86 & Sangat Tinggi \\
\hline $\mathrm{P}_{2} \mathrm{O}_{5}$ Bray II $(\mathrm{ppm})$ & 20,33 & Sedang \\
$\mathrm{K}(\mathrm{me} / 100 \mathrm{~g})$ & 0,009 & Sangat Rendah \\
\hline $\mathrm{Ca}(\mathrm{me} / 100 \mathrm{~g})$ & 0,039 & Sangat Rendah \\
\hline $\mathrm{Mg}(\mathrm{me} / 100 \mathrm{~g})$ & 0,004 & Sangat Rendah \\
\hline $\mathrm{KTK}(\mathrm{me} / 100 \mathrm{~g})$ & 9,02 & Rendah \\
\hline
\end{tabular}

* Berdasarkan klasifikasi hara tanah untuk tanaman karet

Sumber : Adiwiganda et al. (1994) 
Penelitian menggunakan Rancangan Acak Kelompok (RAK) yang terdiri atas 6 perlakuan dan 4 ulangan. Setiap ulangan terdiri atas 49 tanaman sehingga total tanaman yang digunakan sebagai contoh sebanyak 1.176 tanaman. Perlakuan terdiri atas :

1. Kontrol (tanpa pemupukan)

2. $100 \%$ dosis umum pupuk kimia (DU)

3. $2 \mathrm{~kg}$ kompos

4. $1,6 \mathrm{~kg}$ kompos $+25 \%$ dosis umum pupuk kimia (DU)

5. $1,2 \mathrm{~kg}$ kompos $+50 \%$ dosis umum pupuk kimia (DU)

6. $0,8 \mathrm{~kg}$ kompos $+75 \%$ dosis umum pupuk kimia (DU)

Pupuk kimia diaplikasikan pada bulan April 2014 dengan cara membenamkan pupuk dalam lubang (sistem pocket) pada daerah pemupukan (jarak $150 \mathrm{~cm}$ dari batang). Jenis pupuk kimia yang digunakan adalah Urea, TSP, $\mathrm{KCl}$, dan Kieserit, dengan masing-masing dosis sesuai rekomendasi umum untuk TM 8 yaitu pupuk Urea $350 \mathrm{~g} /$ pohon/tahun, TSP sebanyak $200 \mathrm{~g} /$ pohon/tahun, $\mathrm{KCl} 300$ g/pohon/tahun, dan Kieserit 75 g/pohon /tahun. Aplikasi pupuk kimia dilakukan sebanyak 2 kali per tahun pada bulan april dan oktober dengan cara membenamkan pupuk dalam lubang/sistem pocket (Wijaya \& Hidayati, 2012). Aplikasi pupuk kompos dilakukan hanya satu kali pada bulan April 2014 dengan cara pocket. Setiap pohon dibuat empat lubang, yaitu dua lubang di sebelah kiri dan dua lubang di sebelah kanan berjarak 1,0 1,5 $\mathrm{m}$ dari barisan tanaman karet. Parameter pengamatan yang dilakukan terdiri atas:

1) Kandungan hara tanah dan tanaman. Pengamatan kandungan hara tanah dilakukan dengan menganalisis sampel tanah sebelum penelitian dan analisis hara tanaman pada akhir penelitian. Sebelum penelitian, hara tanah dianalisis satu sampel hasil komposit dari areal rencana penelitian, sedangkan di akhir penelitian dilakukan analisis hara tanaman hasil komposit dari 25 pohon sampel pada setiap perlakuan. Metode analisis di laboratorium yang digunakan untuk analisis tanah adalah $\mathrm{pH}\left(\mathrm{H}_{2} \mathrm{O}\right)$ menggunakan $\mathrm{pH}$ meter, $\mathrm{N}$ dengan metode Kjeldahl, $\mathrm{P}$ tersedia dengan metode Bray II, Penetapan kation $\mathrm{K}, \mathrm{Ca}, \mathrm{Mg}$, dan KTK menggunakan ekstrak $\mathrm{NH}_{4} \mathrm{OAc} 1 \mathrm{M}, \mathrm{pH}$ 7. Sedangkan untuk analisis daun semua parameter menggunakan metode pengabuan basah dengan $\mathrm{H}_{2} \mathrm{SO}_{4}$ dan $\mathrm{H}_{2} \mathrm{O}_{2}$, ekstrak yang diperoleh digunakan untuk analisis $\mathrm{N}$ menggunakan metode Kjeldahl, pengukuran $\mathrm{P}$ menggunakan alat Spektrofotometer, pengukuran $\mathrm{K}, \mathrm{Ca} \mathrm{Mg}$ menggunakan AAS (Atomic Absorption Spectroscopy) (Balai Penelitian Tanah, 2009).

2) Pertumbuhan tanaman karet. Pengamatan pertumbuhan tanaman berdasarkan ukuran lilit batang dilakukan saat sebelum aplikasi, 12 dan 24 bulan setelah aplikasi (BSA) pemupukan pertama. Pengamatan lilit batang dilakukan pada ketinggian 100 $\mathrm{cm}$ di atas pertautan okulasi (Kuswanhadi \& Herlinawati, 2018).

3) Tebal kulit pulihan, diukur setiap 12 BSA pada ketinggian $100 \mathrm{~cm}$ diatas pertautan okulasi. Alat yang digunakan adalah sigmat.

4) Produksi tanaman (g/pohon/sadap), pengukuran dilakukan setiap minggu pada setiap plot perlakuan dan ulangan disesuaikan dengan jadwal penyadapan (Saputra et al., 2017).

Masing-masing parameter dilakukan analisis statistik menggunakan program SPSS 16. Data dianalisis secara statistik dengan sidik ragam (ANOVA) untuk mengetahui pengaruh perlakuan. Kemudian dilanjutkan dengan uji lanjutan menggunakan Duncan Multiple Range Test (DMRT) pada taraf 5\% untuk melihat perbedaan antar perlakuan (Hanafiah, 2005). 


\section{Hasil dan Pembahasan}

\section{Pengaruh perlakuan pemupukan terhadap lilit batang dan tebal kulit pulihan}

Hasil pengukuran lilit batang dan tebal kulit sebelum penelitian (0 BSA), setelah 12 bulan dan setelah 24 bulan disajikan pada Tabel 2 dan Tabel 3. Dari data tersebut dapat dilihat bahwa lilit batang dan tebal kulit pada saat sebelum penelitian cukup homogen, lilit batang berkisar antara 56,18 - 59,06 cm dan tebal kulit 6,26 - 6,48 mm. Diharapkan dari kondisi awal tersebut, data yang diperoleh dari hasil penelitian ini merupakan pengaruh dari perlakuan yang diberikan.

Pada saat pengamatan 12 BSA lilit batang tidak menunjukkan perbedaan yang nyata antar perlakuan, namun pada saat pengamatan
24 BSA terdapat perbedaan yang nyata antar perlakuan terhadap lilit batang tanaman. Perlakuan kompos $1,2 \mathrm{~kg}+50 \%$ dosis umum pupuk kimia merupakan perlakuan yang terbaik dengan lilit batang $65,76 \mathrm{~cm}$ dibandingkan perlakuan kontrol yang hanya $62,59 \mathrm{~cm}$. Pengaruh perlakuan terhadap tebal kulit pulihan sampai dengan 24 BSA menunjukkan hasil yang tidak berbeda nyata antar perlakuan, namun semua perlakuan pemupukan memiliki tebal kulit pulihan lebih tinggi dibandingkan dengan kontrol. Hasil penelitian serupa yang dilakukan oleh Saputra \& Stevanus (2017) yang menguji pengaruh perlakuan pemupukan kompos dari tandan kosong kelapa sawit terhadap pertumbuhan tanaman karet belum menghasilkan. Hasil tersebut menunjukkan bahwa perlakuan $100 \%$ dosis umum pupuk kimia memiliki

Tabel 2. Pengaruh perlakuan pemupukan terhadap pertumbuhan lilit batang $(\mathrm{cm})$

\begin{tabular}{lcccccccc}
\hline \multicolumn{1}{c}{ Perlakuan } & 0 BSA & \multicolumn{2}{c}{12 BSA } & \multicolumn{2}{c}{24 BSA } & $\begin{array}{c}\text { Pertambahan lilit } \\
\text { batang 24 BSA }\end{array}$ \\
\hline Kontrol & 57,93 & a & 60,96 & a & 62,59 & ab & 4,66 & ab \\
$100 \%$ DU & 58,14 & a & 61,58 & a & 62,84 & ab & 4,70 & ab \\
Kompos 2 kg & 57,36 & a & 59,97 & a & 60,31 & a & 2,95 & a \\
Kompos $1,6 \mathrm{~kg}+25 \%$ DU & 57,04 & a & 59,61 & a & 60,76 & a & 3,72 & a \\
Kompos $1,2 \mathrm{~kg}+50 \%$ DU & 59,06 & a & 62,32 & a & 65,76 & b & 6,70 & $\mathrm{~b}$ \\
Kompos $0,8 \mathrm{~kg}+75 \%$ DU & 56,18 & a & 59,35 & a & 60,99 & a & 4,81 & ab \\
\hline
\end{tabular}

Keterangan : Angka yang diikuti huruf yang sama pada kolom yang sama menunjukkan tidak terdapat beda nyata antar perlakuan menurut uji Duncan pada tingkat signifikansi 95\%

Tabel 3. Pengaruh perlakuan pemupukan terhadap tebal kulit pulihan

\begin{tabular}{lcccc}
\hline \multirow{2}{*}{ Perlakuan } & \multicolumn{2}{c}{ Tebal Kulit } & Tebal Kulit & Tebal Kulit \\
& Perawan $(\mathrm{mm})$ & Pulihan $(\mathrm{mm})$ & 12 BSA & Pulihan $(\mathrm{mm})$ \\
\hline Kontrol & $6,39 \mathrm{a} A \mathrm{aSA}$ \\
$100 \%$ DU & $6,35 \mathrm{a}$ & $4,56 \mathrm{a}$ & $6,57 \mathrm{a}$ \\
Kompos 2 kg & $6,26 \mathrm{a}$ & $4,78 \mathrm{a}$ & $7,26 \mathrm{a}$ \\
Kompos 1,6 kg + 25\% DU & $6,48 \mathrm{a}$ & $4,53 \mathrm{a}$ & $6,89 \mathrm{a}$ \\
Kompos 1,2 kg + 50\% DU & $6,34 \mathrm{a}$ & $4,65 \mathrm{a}$ & $7,08 \mathrm{a}$ \\
Kompos 0,8 kg + 75\% DU & $6,40 \mathrm{a}$ & $4,73 \mathrm{a}$ & $6,81 \mathrm{a}$ \\
\hline
\end{tabular}

Keterangan : Angka yang diikuti huruf yang sama pada kolom yang sama menunjukkan tidak terdapat beda nyata antar perlakuan menurut uji Duncan pada tingkat signifikansi $95 \%$ 
pertambahan lilit batang tanaman karet belum menghasilkan yang paling tinggi, namun tidak berbeda nyata dengan perlakuan kompos 1,5 $\mathrm{kg}+25 \%$ dosis umum pupuk kimia dan kompos $1 \mathrm{~kg}+50 \%$ dosis umum pupuk kimia.

Pengaruh perlakuan pupuk kimia yang dikombinasikan dengan pupuk kompos memberikan pengaruh nyata terhadap pertumbuhan lilit batang tanaman namun tidak berbeda nyata terhadap pertumbuhan tebal kulit pulihan. Pada pengamatan pertumbuhan lilit batang tanaman 12 BSA terlihat belum ada perlakuan yang berpengaruh nyata dan pada 24 BSA sudah terlihat ada pengaruh dari perlakuan, hal ini dikarenakan masih ada efek residu dari pupuk sebelum dilakukan penelitian. Hal tersebut dikarenakan kompos TKKS memiliki $\mathrm{pH}$ yang tinggi bahkan mencapai $\mathrm{pH} 8$ (Darmosarkoro \& Rahutomo, 2003), sedangkan $\mathrm{pH}$ kompos yang diaplikasikan berkisar 7 - 8. Kondisi $\mathrm{pH}$ kompos yang tinggi tersebut dapat meningkatkan ketersediaan N (Ste-Marie \& Paré, 1999), P (Appelt et al., 1975; Djuniwati et al., 2003), dan K (Darmosarkoro \& Winarna, 2003) pada tanah.

\section{Pengaruh perlakuan pemupukan terhadap produksi tanaman karet}

Pengamatan pengaruh perlakuan terhadap produksi tanaman dilakukan dengan cara pengukuran produksi $(\mathrm{g} / \mathrm{p} / \mathrm{s})$ setiap minggu selama 24 bulan mulai dari bulan Mei 2014 -
Mei 2016. Hasil pengamatan produksi ratarata sampai dengan 24 BSA disajikan pada Tabel 4. Dari data tersebut, terlihat bahwa perlakuan berpengaruh nyata terhadap produksi tanaman mulai dari 6-24 BSA. Ratarata produksi sampai dengan 12 BSA perlakuan $100 \%$ dosis umum pupuk kimia merupakan perlakuan yang terbaik dan tidak berbeda nyata dengan perlakuan kompos $2 \mathrm{~kg}$. Pada saat 18 BSA perlakuan $100 \%$ dosis umum pupuk kimia tidak berbeda nyata dengan perlakuan kompos $1,2 \mathrm{~kg}+50 \%$ dosis umum pupuk kimia dan perlakuan kompos $2 \mathrm{~kg}$. Pada saat 24 BSA perlakuan $100 \%$ dosis umum pupuk kimia tidak berbeda nyata dengan perlakuan kompos $2 \mathrm{~kg}$, kompos 1,6 kg + 75\% dosis umum pupuk kimia, dan kompos $1,2 \mathrm{~kg}$ $+50 \%$ dosis umum pupuk kimia. Pada saat 24 BSA perlakuan yang memberikan pengaruh tertinggi terhadap produksi adalah perlakuan kompos $1,2 \mathrm{~kg}+50 \%$ dosis umum pupuk kimia.

Sampai dengan 12 BSA menunjukkan bahwa perlakuan $100 \%$ dosis umum pupuk kimia merupakan perlakuan yang memberikan pengaruh terbaik terhadap produksi, namun sampai dengan 24 BSA perlakuan pupuk kimia yang dikombinasikan dengan pupuk kompos mulai menunjukkan pengaruh yang lebih baik. Hal tersebut terlihat pada 24 BSA pengaruh perlakuan $100 \%$ dosis umum pupuk kimia memberikan pengaruh yang tidak beda nyata dengan perlakuan kompos $1,6 \mathrm{~kg}+75 \%$ dosis umum pupuk kimia, kompos $1,2 \mathrm{~kg}+50 \%$ dosis umum pupuk kimia dan perlakuan kompos $2 \mathrm{~kg}$. Hal

Tabel 4. Pengaruh perlakuan kompos terhadap produksi rata-rata $(\mathrm{g} / \mathrm{p} / \mathrm{s})$ tanaman karet

\begin{tabular}{lclllllll}
\hline \multicolumn{1}{c}{ Perlakuan } & \multicolumn{2}{c}{$6 \mathrm{BSA}$} & \multicolumn{2}{c}{$12 \mathrm{BSA}$} & \multicolumn{2}{c}{$18 \mathrm{BSA}$} & \multicolumn{2}{c}{$24 \mathrm{BSA}$} \\
\hline Kontrol & 31,82 & $\mathrm{a}$ & 33,13 & $\mathrm{a}$ & 33,31 & $\mathrm{a}$ & 34,67 & $\mathrm{a}$ \\
$100 \% \mathrm{DU}$ & 39,81 & $\mathrm{c}$ & 38,73 & $\mathrm{e}$ & 38,94 & $\mathrm{c}$ & 40,01 & $\mathrm{~b}$ \\
Kompos 2 kg & 37,35 & $\mathrm{bc}$ & 38,12 & $\mathrm{de}$ & 37,66 & $\mathrm{bc}$ & 39,29 & $\mathrm{~b}$ \\
Kompos 1,6 kg + 25\% DU & 35,18 & ab & 35,72 & $\mathrm{bc}$ & 36,65 & $\mathrm{~b}$ & 39,70 & $\mathrm{~b}$ \\
Kompos 1,2 kg + 50\% DU & 34,95 & ab & 36,24 & $\mathrm{~cd}$ & 38,70 & $\mathrm{c}$ & 40,54 & $\mathrm{~b}$ \\
Kompos 0,8 kg + 75\% DU & 32,28 & $\mathrm{a}$ & 33,97 & $\mathrm{ab}$ & 34,91 & $\mathrm{a}$ & 35,94 & $\mathrm{a}$ \\
\hline
\end{tabular}

Keterangan : Angka yang diikuti huruf yang sama pada kolom yang sama menunjukkan tidak terdapat beda nyata antar perlakuan menurut uji Duncan pada tingkat signifikansi $95 \%$ 
ini disebabkan karena pelepasan nutrisi yang dibutuhkan untuk tanaman dari bahan organik sangat lambat (Seran et al., 2010). Rosen \& Bierman (2005) menyatakan bahwa secara umum $70-80 \%$ dari Fosfor (P) dan $80-90 \%$ dari Kalium (K) akan tersedia untuk tanaman pada tahun pertama aplikasi pupuk kandang ataupun kompos. Sementara ketersediaan N lebih kompleks dibandingkan ketersediaan $\mathrm{P}$ dan $\mathrm{K}$ karena sebagian besar bentuk $\mathrm{N}$ pada kompos adalah $\mathrm{N}$ organik. Umumnya pelepasan N-organik di bahan organik seperti pupuk kandang maupun kompos hanya sebesar $25-50 \%$ pada tahun pertama aplikasi karena organik $\mathrm{N}$ akan tersedia untuk tanaman jika mikroorganisme telah mendegradasi bentuk organik dalam kompos menjadi bentuk $\mathrm{N}$-Ammonium.

\section{Pengaruh perlakuan pemupukan terhadap kandungan hara tanaman karet}

Pada akhir penelitian dilakukan pengambilan sampel daun setiap plot perlakuan untuk analisis kandungan hara tanaman dan hasilnya disajikan pada Tabel 5. Berdasarkan analisis statistik tidak terdapat pengaruh yang nyata antar perlakuan disemua kandungan unsur hara tanaman, namun perlakuan pemupukan menunjukkan status hara $\mathrm{N}$ dan $\mathrm{P}$ yang lebih baik dibandingkan dengan kontrol dan pemupukan yang hanya menggunakan pupuk kompos, sedangkan pada perlakuan kompos $1,2 \mathrm{~kg}+50 \%$ dosis umum pupuk kimia dan perlakuan kompos 0,8 $\mathrm{kg}+75 \%$ dosis umum pupuk kimia status hara $\mathrm{K}$ lebih rendah dari kontrol. Peningkatan hara

Tabel 4. Pengaruh perlakuan kompos terhadap produksi rata-rata $(\mathrm{g} / \mathrm{p} / \mathrm{s})$ tanaman karet

\begin{tabular}{|c|c|c|c|c|c|c|c|c|}
\hline Perlakuan & \multicolumn{2}{|c|}{6 BSA } & \multicolumn{2}{|c|}{$12 \mathrm{BSA}$} & \multicolumn{2}{|c|}{$18 \mathrm{BSA}$} & \multicolumn{2}{|c|}{$24 \mathrm{BSA}$} \\
\hline Kontrol & 31,82 & $\mathrm{a}$ & 33,13 & & 33,31 & $\mathrm{a}$ & 34,67 & $\mathrm{a}$ \\
\hline $100 \%$ DU & 39,81 & $\mathrm{c}$ & 38,73 & $\mathrm{e}$ & 38,94 & $\mathrm{c}$ & 40,01 & $\mathrm{~b}$ \\
\hline Kompos $2 \mathrm{~kg}$ & 37,35 & $\mathrm{bc}$ & 38,12 & de & 37,66 & bc & 39,29 & $\mathrm{~b}$ \\
\hline Kompos $1,6 \mathrm{~kg}+25 \% \mathrm{DU}$ & 35,18 & $a b$ & 35,72 & $\mathrm{bc}$ & 36,65 & $\mathrm{~b}$ & 39,70 & $\mathrm{~b}$ \\
\hline Kompos $1,2 \mathrm{~kg}+50 \% \mathrm{DU}$ & 34,95 & $a b$ & 36,24 & $\mathrm{~cd}$ & 38,70 & $\mathrm{c}$ & 40,54 & $\mathrm{~b}$ \\
\hline Kompos $0,8 \mathrm{~kg}+75 \% \mathrm{DU}$ & 32,28 & $\mathrm{a}$ & 33,97 & $a b$ & 34,91 & $\mathrm{a}$ & 35,94 & $\mathrm{a}$ \\
\hline
\end{tabular}

Keterangan : Angka yang diikuti huruf yang sama pada kolom yang sama menunjukkan tidak terdapat beda nyata antar perlakuan menurut uji Duncan pada tingkat signifikansi $95 \%$

Tabel 5. Pengaruh perlakuan kompos terhadap kandungan hara tanaman

\begin{tabular}{|c|c|c|c|c|c|c|}
\hline Perlakuan & N (\%) & & $\mathrm{P}(\%)$ & & K (\%) & \\
\hline Kontrol & $3,26 \mathrm{a}$ & Rendah & $0,22 \mathrm{a}$ & Rendah & $1,31 \mathrm{a}$ & Optimum \\
\hline $100 \%$ DU & $3,51 \mathrm{a}$ & Tinggi & $0,26 \mathrm{a}$ & Rendah & $1,38 \mathrm{a}$ & Optimum \\
\hline Kompos $2 \mathrm{~kg}$ & $3,25 \mathrm{a}$ & Rendah & $0,23 \mathrm{a}$ & Rendah & $1,40 \mathrm{a}$ & Optimum \\
\hline Kompos $1,6 \mathrm{~kg}+25 \% \mathrm{DU}$ & $3,29 \mathrm{a}$ & Rendah & $0,26 \mathrm{a}$ & Rendah & $1,46 \mathrm{a}$ & Tinggi \\
\hline Kompos $1,2 \mathrm{~kg}+50 \% \mathrm{DU}$ & $3,39 \mathrm{a}$ & Optimum & $0,28 \mathrm{a}$ & Rendah & $1,26 \mathrm{a}$ & Rendah \\
\hline Kompos $0,8 \mathrm{~kg}+75 \% \mathrm{DU}$ & $3,30 \mathrm{a}$ & Optimum & $0,23 \mathrm{a}$ & Rendah & $1,26 \mathrm{a}$ & Rendah \\
\hline
\end{tabular}

Keterangan : Angka yang diikuti huruf yang sama pada kolom yang sama menunjukkan tidak terdapat beda nyata antar perlakuan menurut uji Duncan pada tingkat signifikansi 95\%. Status hara rendah, optimum dan tinggi dikelompokkan berdasarkan klasifikasi status hara yang disusun oleh Adiwiganda et al. (1994). 
$\mathrm{N}$ tersebut sejalan dengan penelitian Zulkarnain et al. (2013) yang melaporkan bahwa penambahan pupuk kandang dan kompos dapat meningkatkan dan berpengaruh nyata terhadap kadar $\mathrm{C}$ organik dan nitrogen tanah. Penelitian lebih lanjut dari penelitian ini adalah perhitungan biaya yang lebih efisien antara kombinasi kompos dan pupuk kimia dibandingkan dengan menggunakan pemupukan kimia saja. Perhitungan ekonomi ini juga harus memperhitungkan manfaat jangka panjang dari kompos TKKS karena pengaruh pupuk organik tidak hanya mempunyai pengaruh terhadap sifat kimia tanah, tetapi juga memiliki efek ganda yaitu melalui perbaikan sifat fisik tanah (seperti struktur tanah dan kapasitas pengikat air) dan biologi tanah seperti jumlah mikroorganisme tanah dan total respirasi tanah (Bouajilla \& Sanaa, 2011; Esmaeilzadeh \& Ahangar, 2014; Murphy, 2014).

\section{Perbandingan biaya pemupukan dengan berbagai perlakuan}

Dari hasil pengujian pupuk kompos pada tanaman karet menghasilkan dapat disimpulkan bahwa kombinasi pupuk kompos dari tandan kosong kelapa sawit dengan pupuk kimia dapat mengurangi penggunaan pupuk kimia 50 - 75\%. Dari hasil perbandingan biaya antar perlakuan (Tabel 6), dapat dilihat bahwa perlakuan kompos $2 \mathrm{~kg}$ membutuhkan biaya yang paling rendah, selanjutnya kompos 1,6 kg $+25 \%$ dosis umum pupuk kimia dan perlakuan kompos $1,2 \mathrm{~kg}+50 \%$ dosis umum pupuk kimia. Apabila dilihat dari sisi efisiensi biaya dan pengaruhnya terhadap pertumbuhan dan produksi maka perlakuan yang paling tepat untuk diterapkan pada perkebunan karet adalah kompos 1,2 kg +50\% dosis umum pupuk kimia.

Tabel 6. Kebutuhan biaya aplikasi/ha setiap perlakuan pemupukan

\begin{tabular}{lrrrrr}
\hline \multirow{2}{*}{ Perlakuan } & \multicolumn{2}{c}{ Biaya bahan pupuk (Rp) } & \multirow{2}{*}{$\begin{array}{c}\text { Biaya aplikasi } \\
\text { (Rp) }\end{array}$} & Total Biaya (Rp) \\
\cline { 2 - 3 } & \multicolumn{2}{c}{ Kimia } & Kompos & & - \\
\hline Kontrol & 2.576 .588 & - & 145.500 & 2.722 .088 \\
100\% DU & - & 1.110 .000 & 291.000 & 1.401 .000 \\
Kompos 2 kg & 644.147 & 888.000 & 291.000 & 1.823 .147 \\
Kompos 1,6 kg + 25\% DU & 1.288 .294 & 666.000 & 291.000 & 2.245 .294 \\
Kompos 1,2 kg + 50\% DU & 1.932 .441 & 444.000 & 291.000 & 2.667 .441 \\
Kompos 0,8 kg + 75\% DU & &
\end{tabular}

Catatan: Asumsi harga pupuk Urea Rp. 4.700/kg, TSP Rp. 5.500/kg, KCl Rp. 5.500/kg, Kieserite

Rp. 3.300/kg, dan Kompos Rp. 1.000/kg. Biaya aplikasi pupuk kimia 1,5 HOK dengan biaya @.Rp. 97.000, apabila menggunakan pupuk kombinasi maka menjadi $3 \mathrm{HOK}$.

\section{Kesimpulan}

Perlakuan pemupukan kombinasi antara pupuk kompos dari tandan kosong kelapa sawit dengan pupuk kimia memberikan pengaruh nyata terhadap pertumbuhan lilit batang dan produksi tanaman karet. Secara statistik perlakuan $100 \%$ dosis umum pupuk kimia, kompos $2 \mathrm{~kg}$, kompos $1,6 \mathrm{~kg}+25 \%$ dosis umum pupuk kimia, kompos $1,2 \mathrm{~kg}+$ $50 \%$ dosis umum pupuk kimia tidak berbeda nyata pengaruhnya terhadap produksi tanaman karet. Apabila dilihat dari sisi efisiensi biaya dan pengaruhnya terhadap pertumbuhan dan produksi maka perlakuan yang paling tepat untuk diterapkan pada perkebunan karet adalah kompos $1,2 \mathrm{~kg}+50 \%$ dosis umum pupuk kimia.

\section{Ucapan Terimakasih}

Terima kasih kami ucapkan kepada PT Pinago Utama atas kerjasamanya yang baik dalam kerja sama penelitian dan menyediakan bahan penelitian berupa kompos dari tandan kosong kelapa sawit. Selanjutnya penulis juga mengucapkan banyak terima kasih kepada 
Kepala Balai Penelitian Sembawa atas dukungannya dalam pelaksanaan penelitian dan kepada Sarino, Zartomi dan Syaiful atas bantuannya dalam pelaksanaan penelitian.

\section{Daftar Pustaka}

Adiwiganda, Y. T., Hardjono, A., Manurung, A., Sihotang, U. T. B. D., Sudiharto, Goenadi, D. H., \& Sihombing, H. (1994). Teknik penyusunan rekomendasi pemupukan tanaman karet. Forum Komunikasi Karet, 1-17.

Appelt, H., Coleman, N. T., \& Pratt., P. F. (1975). Interaction between organic compunds, minerals, and ions in volcanicash derived soils: adsorption of benzoate, $\mathrm{p}$ $\mathrm{OH}$ benzoate, salicylate and pthalate ions. Proceedings - Soil Science Society of America, 39(4), 623-627.

Asra, G., Simanungkalit, T., \& Rahmawati, N. (2015). Respons pemberian kompos tandan kosong kelapa sawitdan zeolit terhadap pertumbuhan bibit kelapa sawit di pre nursery. Jurnal Online Agroekoteknologi, 3(1), 416-426.

Balai Penelitian Tanah. (2009). Petunjuk Teknis Analisis Kimia Tanah, Tanaman, Air dan Pupuk. Jakarta, Indonesia: Badan Penelitian dan Pengembangan Pertanian, Departemen Pertanian.

Bouajilla, K., \& Sanaa, M. (2011). Effects of organic amendments on soil phsicochemical and biological properties. Journal of Materials and Environmental Science, 2(S1), 485-490.

Darmosarkoro, W., \& Rahutomo, S. (2003). Tandan kosong kelapa sawit sebagai bahan pembenah tanah. In W. Darmasarkoro, E. S. Sutarta, \& Winarna (Eds.), Lahan dan Pemupukan Kelapa Sawit. Medan: Pusat Penelitian Kelapa Sawit.

Darmosarkoro, W., \& Winarna. (2003). Penggunaan TKS dan kompos TKS untuk meningkatkan pertumbuhan dan produksi tanaman Lahan dan Pemupukan Kelapa Sawit. Medan: Pusat Penelitian Kelapa Sawit.
Darnoko, D., \& Sembiring, T. (2005). Sinergi antara perkebunan kelapa sawit dan pertanian tanaman pangan melalui aplikasi kompos TKS untuk tanaman padi. Tulisan disajikan pada Pertemuan Teknis Kelapa Sawit 2005: Peningkatan Produktivitas Kelapa Sawit Melalui Pemupukan dan Pemanfaatan Limbah PKS., Medan.

Direktorat Jenderal Perkebunan. (2018). Statistik Perkebunan Indonesia, Karet. Jakarta, Indonesia: Direktorat Jenderal Perkebunan.

Djuniwati, S., Hartono, A., \& Indriyati, L. (2003). Pengaruh bahan organik (Pueraria javanica) dan fosfat alam terhadap pertumbuhan dan serapan $\mathrm{P}$ tanaman jagung (Zea mays) pada Andisol Pasir Sarongge. Jurnal Tanah dan Lingkungan, $5(1), 17-22$.

Esmaeilzadeh, J., \& Ahangar, G. (2014). Influence of soil organic matter content on soil physical, chemical, and biological properties. International Journal of Plant, Animal and Environmental Sciences, 4(4), 244-252.

Hanafiah, K. A. (2005). Rancangan percobaan: teori dan aplikasi (10th ed.). Jakarta, Indonesia: PT Raja Grafindo Persada.

Harbianto, Armaini, G., \& Idwar. (2015). Pengaruh kompos tkks dan abu boiler kelapa sawit terhadap pertumbuhan dan produksi tanaman bawang merah (Allium ascalonicum L.). Jurnal Online Mahasiswa Fakultas Pertanian Universitas Riau, 2(2), 114.

Hidayat, A., \& Mulyani, A. (2002). Lahan Kering untuk Pertanian. In A. Abdurachman, Mappaona, \& Saleh (Eds.), Teknologi Pengelolaan Lahan Kering Menuju Pertanian Produktif dan Ramah Lingkungan. Bogor: Pusat Penelitian dan Pengembangan Tanah dan Agroklimat.

Junaedi, A. (2012). Pengaruh kompos dan pupuk NPK terhadap peningkatan kualitas bibit cabutan Shorea leprosula Miq. Jurnal Penelitian Konservasi Hutan dan Konservasi, 9(4), 373-383. 
Kuswanhadi, \& Herlinawati, E. (2018). Penyadapan tanaman karet. In A. Vachlepi, Sahuri, S. Ismawanto, C. T. Stevanus, \& M. Aji (Eds.), Saptabina Usahatani Karet Rakyat 8th ed. Palembang: Balai Penelitian Sembawa.

Loong, S. G., Nazeeb, M., \& Letchumanan, A. (1987). Optimizing the use of FFB much on oil palms on two different soils. Tulisan disajikan pada The 1987 International Oil Palm/Palm Oil Conferences: progress and prospects, Bangi.

Mangoensoekardjo, \& Semangun. (2005). Manajemen Agribisnis Kelapa Sawit. Yogyakarta, Indonesia: Universitas Gadjah Mada Press.

Murphy, B. W. (2014). Soil organic matter and soil function-review of the literature and underlying data. Canberra, Australia: Department of the Environment.

Prasetyo, B. H., \& Suriadikarta, D. A. (2006). Karakteristik, potensi, dan teknologi pengelolaan tanah ultisol untuk pengembangan pertaian lahan kering di Indonesia. Jurnal Penelitian Dan Pengembangan Pertanian, 25(2), 39-47.

Rosen, C. J., \& Bierman, P. M. (2005). Using manure and compost as nutrient sources for vegetable crops. diakses dari https://www.plantgrower.org/.../manureand-compost.pdf:

Saputra, J., \& Stevanus, C. T. (2017, 9 November). Pengaruh kompos tandan kosong kelapa sawit terhadap pertumbuhan tanaman karet belum menghasilkan. Tulisan disajikan pada Seminar Nasional dalam Rangka Dies Natalis ke-54 Fakultas Pertanian Universitas Sriwijaya, Palembang.
Saputra, J., Wijaya, T., Ardika, R., \& Stevanus, C. T. (2017). Uji adaptasi beberapa klon karet pada elevasi tinggi. Jurnal Penelitian Karet, 35(1), 15-22.

Seran, T. H., Srikrishnah, S., \& Ahamed, M. M. Z. (2010). Effect of different levels of inorganic fertilizer and compost as basal application of the growth and yield of onion (Allium cepa L.). The Journal of Agricultural Science, 5(2), 64-70.

Ste-Marie, C., \& Paré, D. (1999). Soil, pH, and $\mathrm{N}$ availability effects on net nitrification in the forest floors of a range of boreal forest stands. Soil Biology and Biochemistry, 31(11), 1579-1589.

Sukandar, Nelvia, \& Ardian. (2014). Aplikasi campuran kompos tkks dengan abu boiler dan pupuk nitrogen terhadap beberapa komponen hasil dan kandungan protein beras. Jurnal Online Agroteknologi, 1(1), 1-7.

Wijaya, T., \& Hidayati, U. (2012). Saptabina usahatani karet rakyat. In $M$. Lasminingsih, H. Suryaningtyas, C. Nancy, \& A. Vachlepi (Eds.), Pemupukan. Palembang: Balai Penelitian Sembawa.

Wijaya, T., Silalahi, J., Purba, B., \& Novikasari, R. (2010, 27-28 Juli). Pemanfaatan tandan kosong sawit untuk pembuatan pupuk organik di PT. Piango Utama. Tulisan disajikan pada Seminar Nasional Teknologi Pemupukan 2010, Palembang.

Zulkarnain, M., Prasetya, B., \& Soemarno. (2013). Pengaruh kompos, pupuk kandang, dan custom-bio terhadap sifat tanah, pertumbuhan dan hasil tebu (saccharum officinarum 1.) pada entisol di kebun Ngrangkah-Pawon, Kediri. Indonesian Green Technology Journal, 2(1), 45-52. 